Learning the Media 


\title{
Learning the Media
}

\section{An Introduction to Media Teaching}

\author{
Manuel Alvarado
}

Robin Gutch

Tana Wollen

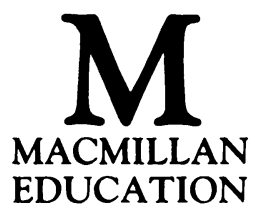


(C) Manuel Alvarado, Robin Gutch and Tana Wollen 1987

Softcover reprint of the hardcover 1st edition 1987

All rights reserved. No reproduction, copy or transmission of this publication may be made without written permission.

No paragraph of this publication may be reproduced, copied or transmitted save with written permission or in accordance with the provisions of the Copyright Act 1956 (as amended), or under the terms of any licence permitting limited copying issued by the Copyright Licensing Agency, 7 Ridgmount Street, London WC1E 7AE.

Any person who does any unauthorised act in relation to this publication may be liable to criminal prosecution and civil claims for damages.

First published 1987

Published by

MACMILLAN EDUCATION LTD

Houndmills, Basingstoke, Hampshire RG21 2XS

and London

Companies and representatives

throughout the world

Typeset by Wessex Typesetters

(Division of The Eastern Press Ltd)

Frome, Somerset

British Library Cataloguing in Publication Data

Alvarado, Manuel

Learning the media.

1. Mass media-Study and teaching-

Great Britain

I. Title II. Gutch, Robin III. Wollen,

Tana

302.2'34'071041 P91.5.G7

ISBN 978-0-333-30522-5 ISBN 978-1-349-18681-5 (eBook)

DOI 10.1007/978-1-349-18681-5 
Remembering Bill Bonney 


\section{FILM-PERCEPTION \\ OF THE WORLD}

The most fundamental point: use of the

\begin{tabular}{|c|}
\hline MAKE W A Y \\
FOR THE \\
MACHINE! \\
\hline
\end{tabular}

camera as a cinema-eye more perfect than the human eye for exploring the chaos of visual phenomena filling the universe ...

... I am cinema-eye - I am a mechanical eye. I, a machine, show you a world such as only I can see.

From now on and for always I cast off human immobility, I move constantly, I approach and pull away from objects. I creep under them, I leap onto them, I move alongside the mouth of a galloping horse, I cut into a crowd, I run before charging troops, I turn on my back, I take off with an air-plane, I fall and rise with falling and rising bodies ... .

My mission is the creation of a new perception of the world. Thus I decipher in a new way a world unknown to you.

Dziga Vertov 


\section{Contents}

Acknowledgements

ix

$\begin{array}{ll}\text { Introduction } & 1\end{array}$

1 Histories 9

Sociological $\quad 10$

Cultural 14

'Skills' 28

Political $\quad 35$

2 Institutions 39

What's in a picture? 39

Why teach media institutions? 45

Mapping courses $\quad 48$

Television as institution $\quad 54$

Institutional structures $\quad 60$

Institutional controls $\quad 74$

$\begin{array}{ll}\text { Alternatives } & 90\end{array}$

3 Realism $\quad 94$

The image $\quad 99$

Documentary 105

Drama 108

Actuality 113

4 Narrative 119

5 Class 141

Beginning classes 141

Class representation of classes $\quad 147$

Media classes $\quad 152$

$\begin{array}{ll}\text { Teaching 'the nation' } & 170\end{array}$ 
6 Gender 177

Woman as body 180

Women in domestic labour $\quad 185$

$\begin{array}{ll}\text { Women in paid work } & 188\end{array}$

$\begin{array}{ll}\text { Adolescence and romance } & 191\end{array}$

7 Race 195

Contexts 195

Social classification of racial difference 199

The 'Exotic' $\quad 204$

The 'Dangerous' 209

The 'Humorous' $\quad 216$

$\begin{array}{ll}\text { The 'Pitied' } & 218\end{array}$

8 Age $\quad 225$

Children $\quad 230$

$\begin{array}{ll}\text { Youth } & 239\end{array}$

Old age $\quad 243$

9 Audiences $\quad 249$

$\begin{array}{ll}\text { The education system } & 251\end{array}$

The media system $\quad 252$

The television audience $\quad 255$

Image analysis and the audience $\quad 260$

$\begin{array}{ll}\text { Postscript } & 267\end{array}$

$\begin{array}{ll}\text { Notes } & 269\end{array}$

$\begin{array}{ll}\text { Bibliography } & 276\end{array}$

$\begin{array}{ll}\text { Index } & 297\end{array}$ 


\section{Acknowledgements}

We would especially like to thank Dave Stewart and to acknowledge the following people for their critical encouragement: David Barrat, Jim Cook, Jenny Grahame, Steven Kennedy, Netia Mayman, John Morey, John Mullan, Jim Pines, Keith Povey, Philip Simpson and Sarah Turvey.

The two John Sturrock photographs and the Mike Goldwater photograph are reproduced courtesy of Network Photographers; the BARB ITV area map is reproduced courtesy of the Broadcaster's Audience Research Board Limited who hold the copyright; Christine Fitzmaurice's drawing of Terry Wogan is reproduced courtesy of the artist and of Radio Times; the Guinness advertisement is reproduced courtesy of Guinness Brewing; René Magritte's Time Transfixed (1932) (Oil on Canvas) $\left(57^{3 \prime \prime} \times 382^{\prime \prime}\right)$, The Art Institute of Chicago, is reproduced with the permission of The Art Institute of Chicago; two photographs from The Visit are reproduced courtesy of the ILEA English Centre; the Andrew Kolesnikow photograph and editorial copy are reproduced courtesy of Homes and Gardens and Syndication International; the feature on Dynasty outfits (which is editorial copy and not an advertisement) is reproduced courtesy of Weekend magazine; the Volvo advertisement is reproduced courtesy of Volvo Concessionaires Ltd and Abbot, Mead Vickers Ltd; the review of C.A.T.S. Eyes by Margaret Forwood is reproduced courtesy of The Sunday People; the photograph of the Notting Hill Carnival is reproduced courtesy of Popperfoto; the still from Sanders of the River is reproduced courtesy of London Films; the photograph of Neil and Glenys Kinnock at the Notting Hill Carnival is reproduced courtesy of The Guardian; Roderick Edbon's photograph of Frank Bruno and Susan Penhaligon and the photograph of Shirley Strong are copyright 1986 TV Times and are reproduced by permission of Transworld Feature Syndicate 
UK Ltd; we would like to thank Steve Bell for his 'IF' cartoon from The Guardian; Thomas Gainsborough's 'Portrait of Miss Haverfield' is reproduced by permission of the Trustees, The Wallace Collection, London; the advertisement 'Playmates' is reproduced courtesy of A \& F Pears Ltd; the front cover of Mother is reproduced courtesy of Mother, IPC Magazines; the advertisement 'Famine Knows No Borders' is reproduced courtesy of International Christian Relief; the article 'Let's Play Strikes . . ., dated Friday, 26 April 1985, is reproduced courtesy of the Daily Mail; the front page of The Sun is reproduced courtesy of The Sun; the stills from Rebel Without A Cause and from Mildred Pierce are reproduced courtesy of Warners; the still from Sunset Boulevard is reproduced courtesy of Paramount; Rod Morrison's photograph of Miss Elizabeth Wright is reproduced with the permission of Help the Aged; Graham Finlayson's photograph of Nazarré is reproduced courtesy of The Observer; the publicity still and poster of The Eyes of Laura Mars are reproduced courtesy of Columbia.

Manuel Alvarado Robin Gutch Tana Wollen 